\title{
MANAGEMENT OF ENDOCRINE DISEASE Pitfalls on the replacement therapy for primary and central hypothyroidism in adults
}

\author{
Gisah Amaral de Carvalho', Gilberto Paz-Filho² ${ }^{\mathbf{1}}$ Cleo Mesa Junior ${ }^{\mathbf{1}}$ and Hans Graf ${ }^{\mathbf{1}}$ \\ 'Department of Endocrinology and Metabolism, SEMPR, Hospital de Clínicas, Federal University of Paraná, Curitiba, \\ Brazil and ${ }^{2} J a n s s e n-C i l a g$ Australia, Sydney, Australia
}

Correspondence should be addressed to $\mathrm{G}$ A de Carvalho Email

carvalho.gisah@gmail.com

\begin{abstract}
Hypothyroidism is one of the most common hormone deficiencies in adults. Most of the cases, particularly those of overt hypothyroidism, are easily diagnosed and managed, with excellent outcomes if treated adequately. However, minor alterations of thyroid function determine nonspecific manifestations. Primary hypothyroidism due to chronic autoimmune thyroiditis is largely the most common cause of thyroid hormone deficiency. Central hypothyroidism is a rare and heterogeneous disorder characterized by decreased thyroid hormone secretion by an otherwise normal thyroid gland, due to lack of TSH. The standard treatment of primary and central hypothyroidism is hormone replacement therapy with levothyroxine sodium (LT4). Treatment guidelines of hypothyroidism recommend monotherapy with LT4 due to its efficacy, long-term experience, favorable side effect profile, ease of administration, good intestinal absorption, long serum half-life and low cost. Despite being easily treatable with a daily dose of LT4, many patients remain hypothyroid due to malabsorption syndromes, autoimmune gastritis, pancreatic and liver disorders, drug interactions, polymorphisms in DIO2 (iodothyronine deiodinase 2), high fiber diet, and more frequently, non-compliance to LT4 therapy. Compliance to levothyroxine treatment in hypothyroidism is compromised by daily and fasting schedule. Many adult patients remain hypothyroid due to all the above mentioned and many attempts to improve levothyroxine therapy compliance and absorption have been made.
\end{abstract}

European Journal of Endocrinology

(2018) 178, R231-R244

\section{Introduction}

Hypothyroidism is the most common thyroid disorder in adults, affecting women more frequently, and incidence of which increases with age. Its clinical presentation ranges from asymptomatic to severe, with myxedema coma presenting as the most severe complication $(1,2)$. The severity of the clinical manifestations and health outcomes rely on the duration and degree of thyroid hormone deficiency (3). If untreated, patients with

\section{Invited Author's profile}

G A de Carvalho MD, PhD is the Head of the Thyroid Unit - SEMPR at the Hospital de Clínicas da Universidade Federal do Paraná, Curitiba, Paraná, Brasil and Associate Professor of Endocrinology and Metabolism at Universidade Federal do Paraná. She is also a Board member of Thyroid Department - Endocrine Brazilian Society. Her major research interests include the pathogenesis and treatment of hypothyroidism, diagnosis and treatment of thyroid nodules.

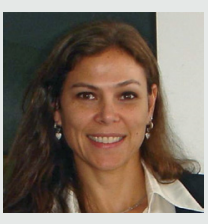


hypothyroidism can be affected by chronic comorbidities such as mood and cognitive disorders, dyslipidemia, infertility and higher risk of delivering children with birth defects (4).

The synthetic thyroid hormone levothyroxine (LT4) is a cost-effective treatment of hypothyroidism, with few side effects (5). The recommended daily dose of LT4 is 1.6$1.7 \mu \mathrm{g} / \mathrm{kg}$ body weight for most patients, which should be taken on an empty stomach, in the morning, 30-60 min prior to breakfast. Besides actual body weight, the LT4 dose depends on other factors, such as TSH goal (normal vs subnormal), ideal body weight, etiology of hypothyroidism, degree of serum TSH elevation, pregnancy and age. For example, athyreotic patients often require a higher LT4 dose than patients with chronic autoimmune thyroiditis. Thyroid hormone therapy can be initiated at full dose in most cases or as partial replacement with gradual increments (starting with $12.5-25 \mu \mathrm{g} /$ day), in elderly, in those with mild or subclinical hypothyroidism, and in those with comorbidities, such as cardiovascular disease. Serum TSH represents the best marker for assessing the proper LT4 dose. The therapeutic target should be individually tailored, based on the patient's diagnosis, age and coexistent diseases $(6,7)$. The bioequivalence between different branded and generic formulations of levothyroxine is an important clinical issue that affects therapy. However, in the absence of prospective trials assessing bioequivalence and effectiveness, it is not possible to affirm that one formulation is superior to another. It is, however, recommended that the same formulation is used throughout therapy, to avoid variations in clinical effectiveness.

The management of hypothyroidism may vary in special populations. In pregnant women with overt hypothyroidism already under treatment, two extra doses per week may be started as soon as pregnancy is confirmed; dose should be titrated to achieve a thyrotropin concentration within the trimester-specific reference range. In patients with myxedema coma, LT4 should be given intravenously, with a loading dose of $200-400 \mu \mathrm{g}$ (less for smaller, older patients or those with heart disease). Until oral therapy can be instituted, the intravenous dose is reduced to $75 \%$ of the usual replacement dose of $1.6 \mu \mathrm{g} / \mathrm{kg}$, and liothyronine may be given in addition to levothyroxine $(5-20 \mu \mathrm{g}$ loading dose and maintenance dose of $2.5-10 \mu \mathrm{g}$ every $8 \mathrm{~h}$ ). In patients with heart disease, low doses of LT4 should be started, with slow increases in the absence of angina or other cardiac symptoms such as tachyarrhythmias.

Many patients fail to show clinical and biochemical response to the expected dose of LT4, which is most frequently attributed to poor compliance (8). In addition, several studies have shown resistance to conventional doses of treatment with oral LT4 in patients with inflammatory bowel disease (9), celiac disease (10), lactose intolerance (11), atrophic gastritis (12) and Helicobacter pylori infection $(13,14)$. Food intake also can interfere with LT4 absorption, with studies showing that fiber supplements, soy protein, coffee and grape fruit can reduce LT4 absorption $(15,16)$. Also, some drugs coadministered with LT4 interfere with its absorption, such as calcium carbonate (17), ferrous sulfate (18), aluminum hydroxide (19), chromium picolinate (20), bile acids resins (21), sucralfate (22), raloxifene (19) and sevelamer (23).

Even after careful consideration of all these factors, discrimination between an unidentified cause of true thyroxine malabsorption and poor LT4 compliance can prove difficult. Thyroxine absorption test, with $1 \mathrm{mg}$ of levothyroxine given in one dose, or weekly administration of LT4 for 4 weeks, may help identify the underlying cause of thyroid hormone deficiency despite proper therapy $(24,25)$.

It has been shown that as many as $40 \%$ of patients on LT4 replacement have TSH serum levels out of the reference range (26), which may lead to clinical signs and symptoms of hypothyroidism and its related comorbidities and determine a negative impact on health-related quality of life (HRQoL) (27). Therefore, adequate LT4 therapy should be given in primary hypothyroidism with the objective to maintain serum TSH within the reference range.

This review will address the pitfalls encountered when treating patients with primary and central hypothyroidism and describe the many strategies to improve levothyroxine therapy compliance and absorption, including new therapeutic alternatives.

\section{Primary hypothyroidism}

\section{Therapeutic alternatives to treat hypothyroidism}

Many studies have shown that up to $40 \%$ of patients with primary hypothyroidism are undertreated and that up to another $40 \%$ may be overtreated - particularly elderly patients $(28,29)$. A study evaluating 339 hypothyroid patients aged 65 years and over showed that more than 40\% had low and 16\% had high TSH levels (28). A study performed in Brazil with 2057 hypothyroid patients showed that more than $80 \%$ of the subjects said they did not follow physician instructions due to prescription misunderstanding or forgetfulness. The prevalences of 
undertreated and overtreated patients in that study were $25.9 \%$ and $14.4 \%$, respectively (30).

Non-compliance is attributed to the limitations and inconveniences imposed by therapy: the needs to take the medication while fasting, to wait approximately $30 \mathrm{~min}$ for the next meal, to take the medication on a daily basis and to avoid medications that may interfere with LT4 absorption (20). Many attempts to improve LT4 therapy compliance have been made, and new therapeutic alternatives have been suggested; weekly administration of LT4 is one of them.

The influence of food intake on LT4 absorption was first reported by Wenzel et al. The absorption of oral LT4 was significantly better if taken while fasting than if taken with simultaneous food intake, $79.3 \%$ and $63.9 \%$, respectively (31). Bevenga and coworkers examined five patients in whom LT4 therapy failed to achieve the target serum TSH through ingestion of LT4 15 min before breakfast. After a month of postponing breakfast for at least 60 min after LT4 ingestion, patients obtained a normal TSH level (32). Bolk and coworkers studied the effects of changing LT4 intake to bedtime. Compared to morning intake, there was a mean decrease in TSH by $1.25 \mathrm{mIU} / \mathrm{L}$, a mean increase in FT4 by $0.07 \mathrm{ng} / \mathrm{dL}$ and an increase in T3 by $6.5 \mathrm{ng} / \mathrm{dL}$ when LT4 was taken at bedtime (33). Bach-Huynh et al. evaluated the effect of the timing of LT4 administration in relation to food on serum TSH (30). They studied 65 patients receiving LT4, and randomized them to different treatment regimens, with intake of LT4 while fasting, with breakfast and at bedtime. Nonfasting regimens of LT4 administration were associated with higher TSH concentrations. The mean TSH was $2.93 \mathrm{mIU} / \mathrm{L}$ when taken with breakfast, $2.19 \mathrm{mIU} / \mathrm{L}$ when taken at bedtime and $1.06 \mathrm{mIU} / \mathrm{L}$ when LT4 was administered while fasting. Considering that LT4 administration at breakfast could be a more convenient treatment scheme, a study was conducted with 45 hypothyroid patients to compare LT4 administration while in a fasting state with administration during breakfast. The TSH level was higher for LT4 administration with breakfast than while fasting, $2.9 \mathrm{mIU} / \mathrm{L}$ and $1.9 \mathrm{mIU} / \mathrm{L}$, respectively (15). These studies showed that despite a mild TSH elevation, TSH levels remained in an acceptable therapeutic range when LT4 was administered with breakfast or at bedtime.

A randomized, crossover study assigned 14 patients to daily or weekly doses of LT4. The weekly treatment led to a transient increase in mean FT4 levels when compared with daily treatment $(1.91$ vs $1.16 \mathrm{ng} / \mathrm{dL}$ for daily vs weekly doses of LT4), without thyrotoxicosis or cardiac symptoms on an echocardiographic evaluation. After
6 weeks, no statistically significant difference was found in mean TSH levels (3.45 vs $1.87 \mathrm{mIU} / \mathrm{L}$ for daily vs weekly doses of LT4) (29) (Fig. 1). Weekly administration of LT4 was safe, well tolerated and without evidence of treatment toxicity, including cardiac effects $(29,34)$.

Those alternative therapeutic regimens for patients who have adherence difficulties due to the need for delaying food intake in the morning could be a good option. For patients in whom a specific serum TSH goal is important, taking levothyroxine while fasting is still the most recommended approach.

\section{Malabsorption syndromes}

Levothyroxine (LT4) is largely absorbed (62-82\%) in small intestine (jejunum and ileum) during the first $3 \mathrm{~h}$ after its ingestion (32). Gastric acidity with an empty stomach enhances LT4 absorption. Euthyroid persons absorb $70-80 \%$ of ingested L-T4 but in hypothyroid patients LT4 absorption is lower (35). Gastrointestinal disorders can interfere with L-T4 absorption in hypothyroid patients. The coexistence of other diseases, which can interfere with levothyroxine absorption should be suspected whenever

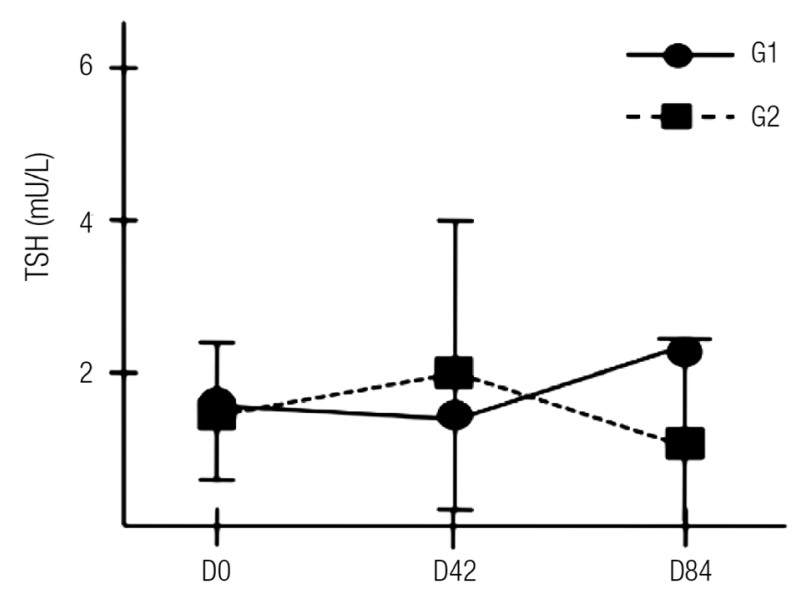

$p>0.05$ for all comparisons between groups and within the same group; Bars: means $\pm S D$.

\section{Figure 1}

Changes in TSH serum levels with daily and weekly regimens of LT4. G1: D0-D42 of daily regimen of LT4 (TSH

$2.03 \pm 1.40 \mathrm{mIU} / \mathrm{L})$ and weekly regimen of $\mathrm{LT} 4$ (TSH

$2.39 \pm 1.19 \mathrm{mIU} / \mathrm{L}) . \mathrm{G} 2$ : D0-D42 of weekly regimen of LT4 (TSH

$3.32 \pm 3.10 \mathrm{mIU} / \mathrm{L}$ and daily regimen of LT4 (TSH

$2.38 \pm 1.37 \mathrm{mIU} / \mathrm{L}) . P>0.05$ for all comparisons between groups and within the same group; bars show means \pm s.D. Adapted from Bornschein A et al. Arq Bras Endocrinol Metab 2012; 56:250-258, with permission. 
high LT4 doses ( $>2 \mu \mathrm{g} / \mathrm{kg}$ of body weight) do not achieve biochemical control in adherent patients (Table 1).

\section{Conditions affecting gastric acidity}

Atrophic gastritis interferes with gastric acidity due to the presence of parietal cell antibodies (PCA) and is often associated with Hashimoto's thyroiditis. Up to $30 \%$ of patients with autoimmune thyroid disease present circulating PCA (2), which target antigen is the pump $\mathrm{H}+/ \mathrm{K}+/$ ATPase located on the apical membrane and in the intracellular space of gastric parietal cells (37, 38). The autoimmune attack leads to the disappearance of the oxyntic glands and to gastric atrophy, which ultimately resultsin chronic gastritis (39). The consequent achlorhydria and decreased intrinsic factor production causes inadequate vitamin B12 absorption (40). The thyroxine molecule changes its conformation due to the reduced gastric acidity with consequent less LT4 absorption in the small intestine (41). In a study involving 391 patients receiving LT4 due to autoimmune thyroid disease, it was shown that $40 \%$ of them had positive PCA and higher LT4 requirement compared to PCA-negative patients $\quad(1.24 \pm 0.40 \mu \mathrm{g} / \mathrm{kg}$ vs $1.06 \pm 0.36 \mu \mathrm{g} / \mathrm{kg})$. LT4 requirement was even higher in patients with gastritis evident on histology (12).

Helicobacter pylori infection is associated with atrophic gastritis, hypochloridria and increased production of ammonia, reducing the efficiency of intestinal absorption of LT4 $(13,14)$. One study evaluating patients with atrophic gastritis and Helicobacter pylori infection showed that those patients required an increase of $34 \%$ in the LT4 dose. Eleven patients were treated for Helicobacter pylori infection and had their TSH levels were measured before and after treatment; their TSH levels were reduced after eradication of infection (13).

Table 1 Main gastrointestinal disorders that interfere with LT4 absorption.

\begin{tabular}{l}
\hline Gastrointestinal disorder \\
\hline Atrophic gastritis \\
Helicobacter pylori infection \\
Celiac disease \\
Lactose intolerance \\
Bowel resection
\end{tabular}

Mechanism

Hypochlorhydria Ammonia production; Increased gastric $\mathrm{pH}$; Inflammation; Intestinal villous atrophy Inflammation Short bowel syndrome

\section{Bowel disorders}

Celiac disease (CD) is an immune-mediated enteropathy that develops in genetically susceptible individuals in response to the ingestion of wheat gluten and related proteins found in barley and rye. Inflammation, hyperplasia of crypts and villous atrophy are some of the histological findings, which may regress or disappear with the removal of gluten from the diet (42). The prevalence of $\mathrm{CD}$ in the population is approximately $1 \%$, and the prevalence of CD in patients with thyroid autoimmune disease is increased - approximately $1.5-5 \%(43,44)$.

Autoimmune thyroid disease and CD coexistence is associated with genetic predisposition demonstrated by HLA-DQ2 an HLA-DQ8 haplotypes (45). Both diseases are related to cytotoxic T-lymphocyte-associated antigen-4 (CTLA-4), associated with susceptibility to autoimmune thyroid disease (46). Adequate $\mathrm{CD}$ treatment reduce inadequate absorption as well as other complications, such as malnutrition, infertility, osteoporosis and lymphoma $(47,48)$. Hypothyroid patients with treated CD present an improvement in LT4 absorption (49). In patients with inadequate control of hypothyroidism even with the use of high doses of levothyroxine, CD must be evaluated (50). However, the impact of the treatment and control of $\mathrm{CD}$ on the risk of developing autoimmune thyroid diseases remains controversial (51).

Lactose intolerance (LI) represents an intestinal disorder due to reduced lactase enzymatic activity that breaks down lactose into glucose and galactose (52). Very active in humans at birth, lactase function declines and persists only in about 30\% throughout adulthood (53). LI may interfere with the absorption of LT4; severe malabsorption of oral LT4 has been described in a patient with LI, primary hypothyroidism and persistently elevated TSH levels, despite treatment with high doses of LT4 ( $>900 \mu \mathrm{g} /$ day). After 3 months of the institution of a lactose-free diet, thyroid function tests were normal (54). Cellini and coworkers analyzed hypothyroid patients due to chronic autoimmune thyroiditis with or without concomitant LI. In all patients with isolated chronic autoimmune thyroiditis, target TSH was obtained at a median LT4 dose of $1.31 \mu \mathrm{g} / \mathrm{kg} /$ day. In patients with LI who were noncompliant with a lactose-free diet, only $14 \%$ reached the desired TSH with a similar LT4 dose. In those patients with isolated LI, a median LT4 dose of $1.72 \mu \mathrm{g} / \mathrm{kg} /$ day was been required to attain pharmacological homeostasis (55), demonstrating that LI increases the need of oral LT4 in hypothyroid patients. 


\section{Intestinal resection}

In recent years, bariatric surgery has been sought by many obese patients. Based on the mechanisms of drug absorption, increased LT4 requirements are expected after bariatric surgery. Some studies have shown that bariatric procedures may modify the absorption of LT4; however, available data are still controversial (11).

A review evaluated the effects of bariatric surgery on levothyroxine dosing. Six of ten studies demonstrated decreased postoperative requirements. Most studies demonstrated inverse correlations between weight loss and dose of LT4; 3 case reports and 1 case series demonstrated increased LT4 requirements, which were attributed to malabsorption.

Loss of fat and lean body mass may counteract malabsorptive effects from surgery, resulting in decreased postoperative levothyroxine requirements (56). The most appropriate approach to date is individual LT4 dose adjustment after bariatric surgery. There are few data concerning the benefits of liquid LT4 in case of impaired absorption determined by bariatric surgery, with one case report demonstrating faster and more efficient absorption of liquid LT4 formulation (57).

\section{Parasitic infestations}

Intestinal parasitosis is a less reported condition involved with LT4 malabsorption $(58,59)$. In a clinical case description, a well-controlled hypothyroid patient started to present symptoms of fatigue, myalgia, cramps, dyspepsia and diarrhea. Laboratory evaluation disclosed a serum TSH $>100 \mathrm{mIU} / \mathrm{L}$, despite an apparent good treatment adherence. Parasitological stool examination showed the presence of Giardia Lamblia and after adequate anti-parasitic treatment, normal thyroid function tests were achieved (58).

In conclusion, different disorders of the digestive tract may potentially interfere in normal LT4 absorption, leading to the requirement of higher LTA doses to control hypothyroidism. Sometimes a picture of uncontrolled hypothyroidism is the first indication of a malabsorption syndrome. The main cause of uncontrolled hypothyroidism is poor patient adherence, but once this is excluded, gastrointestinal disorders, including atrophic gastritis, Helicobacter pylori infection, $\mathrm{CD}$, lactose intolerance, short bowel syndrome and parasitic infestations should be considered as differential diagnoses. Treatment of these disorders should improve the hypothyroidism control.

\section{Combination treatment with LT4 and LT3}

Although the normal thyroid gland secretes both T4 and T3, currently LT4 is the drug of choice for treatment of patients with hypothyroidism. Available LT4 formulations have a half-life of seven days and provide stable blood levels of thyroid hormones after ingestion of oral daily doses (60). Normal TSH and thyroid hormone blood levels are achieved in most patients, with improvements in hypothyroid signs and symptoms. Thus, guidelines from all professional societies recommend LT4 monotherapy as the treatment of choice for all hypothyroid patients (60).

However, approximately $5-10 \%$ of patients given monotherapy complain of symptoms of hypothyroidism, despite their TSH levels being within the normal reference range (61). Mounting evidence suggests that LT4 without the concomitant administration of $\mathrm{T} 3$ cannot assure a euthyroid state in the blood and in all tissues simultaneously and that normal serum TSH levels in patients receiving LT4 monotherapy reflect only pituitary euthyroidism (62). This could be explained by the fact that the peripheral conversion from T4 to T3 is not sufficient to restore normal T3 levels. In humans, about $20 \%$ of circulating T3 is secreted by the thyroid gland, and $80 \%$ of $\mathrm{T} 3$ arises from the $5^{\prime}$-deiodination of $\mathrm{T} 4$ in peripheral tissues.

$\mathrm{T} 3$ is the most active hormone, and its affinity for the nuclear receptors is much stronger than T4. T3 has a half-life of 1 day, and, ideally, three daily doses of $\mathrm{T} 3$ are necessary to determine stable circulating levels (63). Studies of hypothyroid rats failed to show normalization in tissue concentration of T4 and T3 with LT4 monotherapy; only the combination LT4/LT3 (levothyroxine/liothyronine) ensured euthyroidism in all tissues of thyroidectomized rats. In humans, this issue remains controversial and several clinical trials have evaluated the potential role and the efficacy of LT4/LT3 combination therapy (64). The first trial reported in 1970 showed no positive results regarding patient preference toward LT4/LT3 therapy and revealed a high incidence of hyperthyroid symptoms (65). Bunevicius et al. described an increase in well-being, mood and psychometric functionality in patients treated with LT4/LT3 treatment (66), and two other studies also showed similar beneficial effect $(67,68)$. Those findings could not be further replicated by other studies $(69,70,71,72$, 73). The study with the largest sample size, 697 patients, and longest follow-up was conducted by Saravanan and coworkers. That study reported a slight improvement in mood, QoL and anxiety after 3 months of the LT4/LT3 therapy, which was not confirmed subsequently after 
Table 2 Studies evaluating the effects of the treatment with T4 alone vs LT4/LT3 in hypothyroid patients.

\begin{tabular}{|c|c|c|c|c|c|c|c|}
\hline Author & $\begin{array}{l}\text { Study } \\
\text { design }\end{array}$ & $\begin{array}{c}\text { Duration* } \\
\text { (weeks) }\end{array}$ & $\boldsymbol{n}$ & Main outcomes & $\begin{array}{l}\text { Benefits } \\
\text { T3 + T4 > T4 }\end{array}$ & Side effect & Preference \\
\hline Smith et al. (65) & C & 8 & 87 & TFT; QoL & No & Hyper & LT4 \\
\hline Bunevicius et al. (66) & C & 5 & 33 & TFT; QoL & Yes & No & LT4/LT3 \\
\hline Nygaard et al. (67) & C & 12 & 59 & TFT; QoL & Yes & Hyper & LT4/LT3 \\
\hline Fadeyev et al. (68) & $P$ & 24 & 36 & TFT; QoL & Yes & No & LT4/LT3 \\
\hline Kaminski et al. (69) & C & 8 & 32 & TFT; QoL & No & No & No \\
\hline Walsh et al. (70) & C & 10 & 101 & TFT; QoL & No & NR & No \\
\hline Appelhof et al. (71) & $\mathrm{P}$ & 15 & 130 & TFT; QoL & No & NR & LT4/LT3 \\
\hline Rodriguez et al. (72) & C & 13 & 26 & TFT; QoL & No & Hyper & NA \\
\hline Escobar-Morreale et al. (73) & C & 8 & 28 & TFT; QoL & Yes & Low TSH & LT4/LT3 \\
\hline Saravanan et al. (74) & $\mathrm{P}$ & 52 & 697 & TFT; QoL & No & $\begin{array}{l}\text { Hyper } \\
\text { Hypo }\end{array}$ & NA \\
\hline
\end{tabular}

*, Treatment duration; C, crossover; Hyper, hyperthyroidism; NA, not evaluated; NR, not reported; P, parallel; QoL, quality of life; TFT, thyroid function tests.

1 year (74). Based on these studies, some meta-analyses on LT-4/LT-3 therapy did not show any evidence supporting a superior effect of the combination treatment $(75,76)$ (Table 2).

Patients receiving LT4 monotherapy generally have higher T4/T3 ratios than euthyroid individuals, and some of them have normal TSH levels and serum T3 levels at the lower end or below the reference range. Therefore, decreased D2 expression or function could explain the residual complaints in treated hypothyroid patients. Numerous studies have investigated the effects of common genetic variation in the $\mathrm{DIO} 2$ gene on thyroid function tests, thyroid-related outcomes, D2 expression and function $(77,78,79,80,81,82)$. The D2 Thr92Ala polymorphism, the most frequently studied variant, has been associated with insulin resistance, obesity, hypertension, altered bone turnover, cognition and alterations in the HPT axis and in response to thyroid hormone replacement therapy (60). Several studies failed to demonstrate the associations of the $\mathrm{D} 2$ polymorphism Thr92Ala with thyroid function tests, suggesting that this variant does not have an effect on serum thyroid parameters in the general population (77).

Recently, Castagna et al. demonstrated an association between low free T3 values and the Thr92Ala polymorphism in 140 thyroidectomized patients; they also demonstrated that the polymorphism reduced D2-mediated thyroxineto-T3 conversion (83). This discrepancy in findings can be explained by differences in the study design and sample size, among other factors. Most of the studies included predominantly euthyroid individuals $(79,80,81)$. The effects of the Thr92Ala variant become only apparent in athyreotic patients receiving only LT4 and are masked by thyroidal T3 production in euthyroid individuals (77). A large, well-powered study is needed to replicate the effects of the D2 Thr92Ala polymorphism on thyroid function tests in athyreotic patients receiving LT4 to clarify whether these patients are indeed more vulnerable to the effects of this polymorphism. These studies should also investigate whether these effects contribute to the residual complaints that impair the quality of life of $10-20 \%$ of the hypothyroid patients, thus providing evidence in favor of customized treatment of hypothyroidism mainly in athyreotic patients.

\section{Subclinical hypothyroidism}

Subclinical hypothyroidism (SCH) is defined as normal free T4 and free T3 levels in the presence of abnormal elevation of TSH. This condition has been diagnosed more frequently in clinical practice; however, its clinical significance is still much debated (84). Although the term subclinical hypothyroidism suggests an asymptomatic condition, a substantial proportion of patients presents nonspecific symptoms of hypothyroidism $(85,86)$. The prevalence of SCH is relatively high and varies from $4 \%$ to $20 \%$. Its incidence depends on age and sex and is usually more frequent in patients older than 60 years, with a prevalence of about 15\% in women and 8\% in men (87).

$\mathrm{SCH}$ has important clinical implications in overall health and may increase cardiovascular risk due to its association with arterial hypertension, dyslipidemia, endothelial dysfunction, insulin resistance, inflammation and oxidative stress $(84,88,89,90,91,92,93,94)$. There are different questions to ask regarding SCH: are we hyperdiagnosing $\mathrm{SCH}$ ? Are we perhaps hyper-treating $\mathrm{SCH}$ ? Are there different $\mathrm{SCH}$ presentations? When evaluating $\mathrm{SCH}$ patients, it is very important to distinguish between temporary elevations of TSH from persistent and 
progressive TSH elevations, the latter usually associated with chronic autoimmune thyroiditis. According to the Brazilian Society of Endocrinology Guidelines on $\mathrm{SCH}$, TSH levels should be reevaluated after three months to confirm persistent SCH (95). Spontaneous TSH normalization can occur, especially when TSH elevations are mild. This can occur in the presence or absence of antithyroid antibodies, which is frequently with the latter presentation (96).

Chronic autoimmune thyroiditis, the main cause of primary hypothyroidism in children and adults, is a chronic and progressive disease. In individuals with a genetic predisposition, the immune process can be triggered by environmental factors. Very precocious thyroid alterations are detected through ultrasonography, which reveals a heterogeneous and hypoechoic gland, characteristic of an inflammatory process, with the appearance of antithyroid antibodies subsequently. As the process progresses, T4 levels can decrease with an elevation of TSH. This combination of still normal T4 levels and TSH elevation is indicative of minimal thyroid insufficiency $(96,97)$. In the presence of positive antithyroid antibodies, the progression from $\mathrm{SCH}$ to overt hypothyroidism in women occurs in $4.3 \%$ per year (98).

Many drugs can induce $\mathrm{SCH}$, particularly in patients with subjacent autoimmune thyroiditis. Among them, amiodarone, a widely used antiarrhythmic drug, frequently interferes with thyroid hormone production. Beside this, the chronically high iodine levels seen in patients using the drug can enhance the prevalence of chronic autoimmune thyroiditis in genetically susceptible individuals (99). Other drugs that contain iodine, lithium carbonate, cytokines or interferon can also induce SCH (100).

The term subclinical hypothyroidism suggests the absence of symptoms in these patients. However, a high prevalence of patients with $\mathrm{SCH}$ presents signs and symptoms of hormonal deficiency, although less exuberant than in patients with overt hypothyroidism (84). The early diagnosis of $\mathrm{SCH}$ is accompanied by unspecific symptoms, which are reversible with thyroxine replacement. The development of symptoms is related to the disease duration and to the individual sensitivity to thyroid hormone deficiency, which in turn depends on the sensitivity of peripheral target organs (84). Overt hypothyroidism is associated with a higher cardiovascular risk (101). During the last years, with the increasing prevalence of $\mathrm{SCH}$ and the potential progression to overt thyroid disease, cardiovascular dysfunctions have been studied more intensively in SCH (102). Potential cardiovascular risk in $\mathrm{SCH}$ is an important aspect in screening and treatment programs (103). The degree of hemodynamic changes depends on the severity of thyroid hormone deficiency, the increase in systemic vascular resistance (SVR) being one of the most frequently studied dysfunction, together with systolic and diastolic dysfunction $(104,105)$. Those are alterations frequently reversed with thyroid hormone replacement (84).

Epidemiologic and autopsy studies support the higher risk of arteriosclerosis in patients with SCH (84), which are related to hypercholesterolemia and LDL elevations. Furthermore, diastolic hypertension due to elevated SVR, arterial stiffness, endothelial dysfunction, altered coagulability state and elevated PCR levels all can contribute for the higher cardiovascular risk associated with SCH $(89,105,106)$. The most reported cardiac abnormality is left ventricular diastolic dysfunction, characterized by a diminished muscle relaxation time and decreased left ventricular filling (107, 108, 109). Neuromuscular alterations are not uncommon in $\mathrm{SCH}$, probably due to altered glycogenolysis (110), altered expression of myosin heavy chain (111) and a reduction in mitochondrial activity $(112,113)$.

Prospective, randomized, placebo-controlled studies evaluating symptoms improvement with LT4 in patients with $\mathrm{SCH}$ are scarce, with conflicting results probably due to differences in patient recruitment regarding etiology, age and TSH levels at the treatment beginning (84). In a recent randomized study controlled with placebo in elderly patients, there was no difference in the score of hypothyroidism symptoms and of quality of life after 12 months of LT4 treatment (114). Issues regarding this study include mean patient age (74.4 years), mild TSH elevation $(6.4 \pm 2.01 \mathrm{mU} / \mathrm{L})$ and the absence of evident hypothyroid symptoms at the beginning of treatment (115).

What are the consequences of LT4 replacement on cardiovascular risks such as dyslipidemia, insulin resistance, arterial hypertension, inflammation, oxidative stress, endothelial dysfunction and the altered coagulation pattern? Regarding the lipid profile, a recent systematic review and meta-analysis of randomized treatments with LT4 and controlled with placebo demonstrated a significant reduction in LDL cholesterol levels, with compelling evidence in favor of benefits with LT4 treatment (87). Arterial stiffness changes are normalized with LT4 replacement (116). The characteristic left ventricular diastolic dysfunction seen in SCH is normalized with LT4, as reported in many studies $(107,109,117)$. In a doubleblind study controlled with placebo, a decrease in the isovolumetric relaxation time was observed with T4 (26). 
In other clinical trials controlled with placebo, a positive effect in systolic function was also observed with T4 (109, $117,118)$.

Thyroid hormones act on the endothelium and smooth muscle cells, with a key role in vascular tonus modulation (119). There is an inverse correlation between TSH and endothelium-dependent vasodilatation (120, 121). Thyroxine replacement in SCH induces a significant reduction in SVR, median arterial pressure and central arterial stiffness $(122,123,124)$. An evaluation of SCH treatment after six months of stable euthyroidism showed a significant improvement of endothelial function, evidenced by acetylcholine-induced vasodilatation, due to the reestablishment of nitric oxide availability (121). In a double-blind study, brachial arterial flow improved significantly after hormone replacement, independent of other cardiovascular risks (125). Finally, an improvement was observed in treated $\mathrm{SCH}$ patients with coronary microvascular dysfunction (126).

Progressive decrease in thyroid function in patients with autoimmune gland disease is associated with a wide spectrum of manifestations, from early alterations with mild TSH elevation and normal thyroid hormone levels, to overt clinical hypothyroidism. The treatment of SCH patients should be individualized, taking into account factors as age, sex, presence of other comorbidities and treatment adherence. In general, adequate thyroid hormone replacement with thyroxine in $\mathrm{SCH}$ patients is associated with clinical benefits. According to the European Consensus on Subclinical Hypothyroidism, age is an important determinant of the therapeutic approach in patients with $\mathrm{SCH}$. Younger patients $(<65-70$ years) with serum TSH $>10 \mathrm{mU} / \mathrm{L}$ should be treated, even in the absence of symptoms. In those younger patients with serum TSH $<10 \mathrm{mU} / \mathrm{L}$ and with symptoms suggestive of hypothyroidism, a trial of LT4 replacement can be considered. In patients over age 70 years and serum TSH $<10 \mathrm{mU} / \mathrm{L}$, clinical observation is recommended, and thyroid function tests repeated in 6 months; if TSH is equal or higher than $10 \mathrm{mU} / \mathrm{L}$, LT4 therapy can be considered if clear symptoms of hypothyroidism or high cardiovascular risk. Patients over $>80-85$ years with serum TSH $\leq 10 \mathrm{mU} / \mathrm{L}$ should be followed closely, and LT4 therapy less often used (127).

\section{Central hypothyroidism}

Central hypothyroidism $(\mathrm{CH})$ is defined as insufficient thyroid hormone production due to quantitative or qualitative alterations in TSH. $\mathrm{CH}$ can be isolated or combined with other pituitary hormone deficiencies. Congenital or acquired defects causing functional or anatomic disorders of the pituitary gland and/or hypothalamus can lead to $\mathrm{CH}(128,129)$. It is a rare cause of hypothyroidism, affecting 1 of 1000 patients with hypothyroidism (130). The diagnosis is suspected when a low level of free T4 (FT4) is associated with inappropriately normal or low level of TSH $(131,132)$. TSH is normal in most of cases, but it can be low or even slightly elevated in few patients. Total T3 and total T4, as well as free T3, are within the reference range in a significant subset of patients, and FT4 is usually reduced or in the low normal range particularly in the congenital cases $(131,132)$.

In primary hypothyroidism, all recommendations on the diagnosis and treatment are made based on TSH levels, and the definition of subclinical thyroid dysfunction is well established when TSH levels is high and FT4 is normal. In that form of hypothyroidism, FT4 is not an adequate marker of thyroid function (133). However, in $\mathrm{CH}$, as TSH is not a reliable marker of thyroid function, the most important biochemical parameter for the diagnosis and monitoring of the treatment is FT4.

The aim of $\mathrm{CH}$ treatment is to restore euthyroidism $(128,129,130,131,132)$. Levothyroxine is considered the standard treatment as it is inexpensive, worldwide available, has a long half-life of 7 days, lead to more stable serum levels comparing with LT3, enabling the administration of a single daily dose (134). The combination of LT4 and LT3 has not proven to be superior to isolated LT4 therapy and leads to FT3 levels above the reference range in a considerable number of patients (135). Treatment with TRH and TSH is not justifiable because of the prohibitive costs and lack of demonstrated superiority over thyroid hormone replacement (2). Comparing with primary hypothyroidism, $\mathrm{CH}$ patients achieve lower levels of FT4 under LT4 replacement, suggesting possible undertreatment (136). As matter of fact, FT4 levels are higher in patients with primary hypothyroidism adequately treated based on TSH levels, comparing with euthyroid controls, suggesting that the level of FT4 needs to be higher than that in the normal population to maintain an euthyroid state (136). Based on these data from primary hypothyroidism patients, the recommendation to keep FT4 levels in the middle upper level of the normal reference range as a target for $\mathrm{CH}$ patients receiving LT4 seems to be appropriate $(128,129$, 131, 136). Because LT4 determines a peak concentration $2-4 \mathrm{~h}$ after ingestion, it is recommended to perform blood tests before the ingestion of LT4 tablets, to avoid 
the peak concentration $(128,129,134)$. TSH levels are usually low $(<0.5 \mathrm{mU} / \mathrm{L})$ in more than $80 \%$ of patients receiving LT4 (137). Thus, insufficient replacement can be suspected when TSH is inappropriately elevated, above $1 \mathrm{mIU} / \mathrm{L}$ (137). Even though FT3 levels are not a good biochemical marker for the diagnosis in $\mathrm{CH}$, they can be useful for monitoring treatment, as some patients on LT4 replacement can have high-normal FT4 and high FT3 levels, demonstrating overtreatment (137).

The mean average dose of LT4 replacement is around $1.6 \mu \mathrm{g} / \mathrm{kg} /$ day $(131,132)$, and elderly may need a smaller dose $(1.3 \mu \mathrm{g} / \mathrm{kg} / \mathrm{day})(131,132)$. It is recommended to start with low doses $(25-50 \mu \mathrm{g} /$ day $)$ and adjust gradually every 2-3 weeks according with FT4 levels and symptoms $(128,129)$. Caution is necessary when hypothyroidism is associated with untreated corticotropin deficiency, as the restoration of thyroid hormones function can precipitate adrenal crisis in a patient with unrecognized central adrenal insufficiency $(128,129)$. Growth hormone (rhGH) replacement can unmask $\mathrm{CH}$ that was unapparent before rhGH treatment in patients with multiple pituitary deficiencies, but not in isolated GH deficiency (138). GH was found to increase T4 to T3 conversion through type 2 deiodinase activation (139), thus, usually FT4 levels drop in patients with $\mathrm{CH}$ taking LT4 following rhGH replacement therapy. Some experts recommend increased LT4 dose targeting the upper normal reference FT4 range (129). In contrary, other authors found that T3 levels increase after rhGH therapy, which increases the conversion of T4 into T3. In that case, targeting FT4 to the upper normal reference range can lead some patients to overtreatment; thus, it is recommended the monitoring of T3 levels in those patients (140). In addition, estrogen replacement can increase thyroid-binding globulin (TBG) concentrations, warranting increase LT4 dose, regardless of the route of estrogen administration, oral or transdermal (131).

\section{Hypothyroidism induced by anti-cancer drugs}

Special consideration should be given to tyrosine kinase inhibitors (TKIs) used in the treatment of many forms of cancer (including thyroid cancer), which can induce hypothyroidism and thyrotoxicosis. Many different mechanisms have been proposed to explain the TKIs effects on the hypothalamic-pituitary-thyroid axis, which include destructive processes in the thyroid gland (due to inhibition of VEGF and capillary dysfunction), inhibition of thyroid hormone transporters such as MCT8, antithyroid peroxidase antibody production and decreased iodine uptake by the thyroid gland and increased inactivation of thyroid hormone by enhanced type 3 deiodinase activity $(141,142)$.

Thyroid function should be assessed before starting TKIs (such as sunitinib sorafenib, imatinib, dasatinib, nilotinib and axitinib), which should be monitored during and after the end of treatment. The medium time to hypothyroidism onset is variable, and treatment with levothyroxine may be considered during TKI therapy. After TKIs withdrawal, some patients remain hypothyroid and others recover a normal thyroid function, warranting discontinuation of levothyroxine replacement (143).

Other anti-cancer immunomodulatory targeted therapies may also be involved in the pathogenesis of thyroid dysfunction, such as cytokine-based therapies (e.g. interferons and interleukins) and monoclonal antibodies (such as ipilimumab and alemtuzumab). Similar approach is recommended in such cases (142).

\section{Conclusions}

The hypothyroid spectrum, from $\mathrm{SCH}$ to overt hypothyroidism, is a common disorder that is managed, in most cases, with daily oral administration of LT4. Physicians should be aware of the peculiarities regarding the diagnosis, treatment and monitoring of $\mathrm{SCH}$ and the forms of overt hypothyroidism, central and primary.

Most patients achieve euthyroidism with such approach, but some cases are refractory to therapy. Those cases warrant further investigation to identify the underlying cause of lack of response to LT4 therapy, and poor compliance is the most common factor. Other contributing causes include malabsorption syndromes, and concomitant use of drugs that interfere with the LT4 pharmacokinetic profile. In case of noncompliant patients, different strategies can be attempted, such as weekly administration of LT4 and change of the timing of LT4 administration.

Despite achieving biochemical euthyroidism, some patients sustain symptoms of hypothyroidism. Several animal studies have attributed this to low tissular levels of T3 despite proper LT4 therapy, but clinical trials have failed to consistently demonstrate a benefit of combination LT4/LT3 therapy. However, in selected patients, the use of combination therapy may be considered. 
Declaration of interest

G P F is an employee of Janssen-Cilag. The remaining authors declare no financial or other potential conflicts of interest.

\section{Funding}

This research did not receive any specific grant from any funding agency in the public, commercial or not-for-profit sector.

Author contribution statement

All authors contributed to the preparation of this review.

\section{References}

1 Golden SH, Robinson KA, Saldanha I, Anton B \& Ladenson PW. Clinical review: prevalence and incidence of endocrine and metabolic disorders in the United States: a comprehensive review. Journal of Clinical Endocrinology and Metabolism 200994 1853-1878. (https://doi.org/10.1210/jc.2008-2291)

2 Roberts CG \& Ladenson PW. Hypothyroidism. Lancet 2004363 793-803. (https://doi.org/10.1016/S0140-6736(04)15696-1)

3 Cooper DS \& Biondi B. Subclinical thyroid disease. Lancet 2012379 1142-1154. (https://doi.org/10.1016/S0140-6736(11)60276-6)

4 Baskin HJ, Cobin RH, Duick DS, Gharib H, Guttler RB, Kaplan MM, Segal RL \& American Association of Clinical Endocrinologists. American Association of Clinical Endocrinologists American Association of Clinical Endocrinologists medical guidelines for clinical practice for the evaluation and treatment of hyperthyroidism and hypothyroidism. Endocrine Practice 20028 457-469. (https://doi. org/10.4158/1934-2403-8.6.457)

5 Harington CR \& Barger G. Chemistry of thyroxine-constitution and synthesis of thyroxine. Biochemestry Journal 192721 169-183. (https://doi.org/10.1042/bj0210169)

6 Hays MT. Absorption of oral thyroxine in man. Journal of Clinical Endocrinology and Metabolism 196828 749-756. (https://doi. org/10.1210/jcem-28-6-749)

7 Hays MT. Localization of human thyroxine absorption. Thyroid 1991 1 241-248. (https://doi.org/10.1089/thy.1991.1.241)

8 Ain KB, Refetoff S, Fein HG \& Weintraub BD. Pseudomalabsorption of levothyroxine. JAMA 1991266 2118-2120. (https://doi. org/10.1001/jama.1991.03470150090036)

9 Liwanpo L \& Hershman JM. Conditions and drugs interfering with thyroxine absorption. Best Practice and Research: Clinical Endocrinology and Metabolism 200923 781-792. (https://doi.org/10.1016/j. beem.2009.06.006)

10 McDermott JH, Coss A \& Walsh CH. Celiac disease presenting as resistant hypothyroidism. Thyroid 200515 386-388. (https://doi. org/10.1089/thy.2005.15.386)

11 Muñoz-Torres M, Varsavsky M \& Alonso G. Lactose intolerance revealed by severe resistance to treatment with levothyroxine. Thyroid 200616 1171-1173. (https://doi.org/10.1089/ thy.2006.16.1171)

12 Checchi S, Montanaro A, Pasqui L, Ciuoli C, De Palo V, Chiappetta MC \& Pacini F. L-thyroxine requirement in patients with autoimmune hypothyroidism and parietal cell antibodies. Journal of Clinical Endocrinology and Metabolism 200893 465-469. (https://doi. org/10.1210/jc.2007-1544)

13 Centanni M, Gargano L, Canettieri G, Viceconti N, Franchi A, Delle Fave G \& Annibale B. Thyroxine in goiter, Helicobacter pyloriinfection, and chronic gastritis. New England Journal of Medicine 2006354 1787-1795. (https://doi.org/10.1056/NEJMoa043903)

14 Lahner E, Annibale B \& Delle Fave G. Systematic review. Helicobacter pylori infection and impared drug absorption.
Alimentary Pharmacology and Therapy 200929 379-386. (https://doi. org/10.1111/j.1365-2036.2008.03906.x)

15 Perez CL, Araki FS, Graf H \& de Carvalho GA. Serum thyrotropin levels following levothyroxine administration at breakfast. Thyroid 201323 779-784. (https://doi.org/10.1089/thy.2012.0435)

16 Bell DS \& Ovalle F. Use of soy protein supplement and resultant need for increased dose of levothyroxine. Endocrine Practice 20017 193-194. (https://doi.org/10.4158/EP.7.3.193)

17 Singh N, Singh PN \& Hershman JM. Effect of calcium carbonate on the absorption of levothyroxine. JAMA $20002832822-2825$. (https://doi.org/10.1001/jama.283.21.2822)

18 Campbell NR, Hasinoff BB, Stalts H, Rao B \& Wong N. Ferrous sulfate reduces thyroxine efficacy in patients with hypothyroidism. Annals of Internal Medicine 1992117 1010-1013. (https://doi. org/10.7326/0003-4819-117-12-1010)

19 Siraj ES, Gupta MK \& Reddy SSK. Raloxifene causing malabsorption of levothyroxine. Archives of Internal Medicine 2003163 1367-1370. (https://doi.org/10.1001/archinte.163.11.1367)

20 John-Kalarickal J, Pearlman G \& Carlson HE. New medications which decrease levothyroxine absorption. Thyroid 200717 763-765. (https://doi.org/10.1089/thy.2007.0060)

21 Northcutt RC, Stiel JN, Hollifield JW \& Stant EG Jr. The influence of cholestyramine on thyroxine absorption. JAMA 1969208 1857-1861. (https://doi.org/10.1001/ jama.1969.03160100047012)

22 Sherman SI, Tielens ET \& Ladenson PW. Sucralfate causes malabsorption of L-thyroxine. American Journal of Medicine 199496 531-535. (https://doi.org/10.1016/0002-9343(94)90093-0)

23 Diskin CJ, Stokes TJ, Dansby LM, Radcliff L \& Carter TB. Effect of phosphate binders upon TSH and L-thyroxine dose in patients on thyroid replacement. International Urology and Nephrology 200739 599-602. (https://doi.org/10.1007/s11255-006-9166-6)

24 Walker JN, Shillo P, Ibbotson V, Vincent A, Karavitaki N, Weetman AP, Wass JA \& Allahabadia A. A thyroxine absorption test followed by weekly thyroxine administration: a method to assess non-adherenceto treatment. European Journal of Endocrinology 2013 168 913-917. (https://doi.org/10.1530/EJE-12-1035)

25 Pedrosa W \& Santana G. Pseudomalabsorption of levothyroxine: a case report. Arquivos Brasileiros de Endocrinologia e Metabologia 200549 308-313. (https://doi.org/10.1590/S000427302005000200020)

26 Vigário Pdos S, Vaisman F, Coeli CM, Ward L, Graf H, Carvalho G, Júnior RM \& Vaisman M. Inadequate levothyroxine replacement for primary hypothyroidism is associated with poor health-related quality of life-a Brazilian multicentre study. Endocrine $2013 \mathbf{4 4}$ 434-440. (https://doi.org/10.1007/s12020-013-9886-1)

27 Samuels MH, Schuff KG, Carlson NE, Carello P \& Janowsky JS. Health status, psychological symptoms, mood, and cognition in L-thyroxine-treated hypothyroid subjects. Thyroid 200717 249-258. (https://doi.org/10.1089/thy.2006.0252)

28 Somwaru LL, Arnold AM, Joshi N, Fried LP, Cappola AR. High frequency of and factors associated with thyroid hormone overreplacement and under-replacement in men and women aged 65 and over. Journal of Clinical Endocrinology and Metabolism 200994 1342-1345. (https://doi.org/10.1210/jc.2008-1696)

29 Bornschein A, Paz-Filho G, Graf H \& Carvalho GA. Treating primary hypothyroidism with weekly doses of levothyroxine: a randomized, single-blind, crossoverstudy. Arquivos Brasileiros de Endocrinologia e Metabologia 201256 250-258. (https://doi.org/10.1590/S000427302012000400006)

30 Bagattoli RM, Vaisman M, Lima JS \& Ward LS. Estudo de adesão ao tratamento do hipotiroidismo. Arquivos Brasileiros de Endocrinologia e Metabologia 200044 483-487. (https://doi.org/10.1590/S000427302000000600006)

31 Wenzel KW \& Kirschsieper HE. Aspects of the absorption of oral L-thyroxine in normal man. Metabolism 197726 1-8. (https://doi. org/10.1016/0026-0495(77)90121-4) 
32 Benvenga S, Bartolone L, Squadrito S, Lo Giudice F \& Trimarchi F. Delayed intestinal absorption of levothyroxine. Thyroid 19955 249-253. (https://doi.org/10.1089/thy.1995.5.249)

33 Bach-Huynh TG, Nayak B, Loh J, Soldin S \& Jonklaas J. Timing of levothyroxine administration affects serum thyrotropin concentration. Journal of Clinical Endocrinology and Metabolism 2009 94 3905-3912. (https://doi.org/10.1210/jc.2009-0860)

34 Grebe SKG, Cooke RR, Ford HC, Fagerström JN, Cordwell DP, Lever NA, Purdie GL \& Feek CM. Treatment of hypothyroidism with once weekly thyroxine. Journal of Clinical Endocrinology and Metabolism 199782 870-875. (https://doi.org/10.1210/ jcem.82.3.3830)

35 Asvold BO, Bjøro T \& Vatten LJ. Association of serum TSH with high body mass differs between smokers and never-smokers. Journal of Clinical Endocrinology and Metabolism 200994 5023-5027. (https:// doi.org/10.1210/jc.2009-1180)

36 Carvalho GA \& Fighera TM. Effect of gastrointestinal disorders in autoimmune thyroid diseases. Translational Gastrointestinal Cancer 20144 76-82. (https://doi.org/10.3978/j.issn.2224-4778.2014.07.03)

37 D'Elios M, Bergman M, Azzurri A, Amedei A, Benagiano M, De Pont J, Cianchi F, Vandenbroucke-Grauls C, Romagnani S, Appelmelk B et al. H/K-ATPase (proton pump) is the target autoantigen of Th1-Type cytotoxic T cells in autoimmune gastritis. Gastroenterology $2001 \mathbf{1 2 0}$ 377-386.

38 Utiyama SRR, De Bem RS, Skare TL, De Carvalho GA, Teixeira LM, Bertolazo M, Ioshii SO \& Nisihara R. Anti-parietal cell antibodies in patients with autoimmune thyroid diseases. Journal of Endocrinological Investigation 2017 Epub. (https://doi.org/10.1007/ s40618-017-0755-2)

39 Claeys D, Faller G, Appelmelk BJ, Negrini R \& Kirchner T. The gastric $\mathrm{H} / \mathrm{K}-\mathrm{ATP}$ ase is a major autoantigen in chronic Helicobacter pylori gastrites with body mucosa atrophy. Gastroenterology $1998 \mathbf{1 1 5}$ 340-347. (https://doi.org/10.1016/S0016-5085(98)70200-8)

40 Del Valle J. Harrison's Principles of Internal Medicine. 15 ed., Vol 2, pp 1762-1763, 2001. McGraw-Hill, New York City: New York, USA

41 Ward LS. The difficult patient: drug interaction and the influence of concomitant diseases on the treatment of hypothyroidism. Arquivos Brasileiros de Endocrinologia e Metabologia 201054 435-442. (https:// doi.org/10.1590/S0004-27302010000500002)

42 Ch'ng CL, Jones MK \& Kingham JGC. Celiac disease and autoimmune thyroid disease. Clinical Medicine and Research 20073 184-192. (https://doi.org/10.3121/cmr.2007.738)

43 Ferguson A, Arranz E \& O'Mahony S. Clinical and pathological spectrum of coeliac disease-active, silent, latent, potential. Gut 1993 34 150-151. (https://doi.org/10.1136/gut.34.2.150)

44 Teixeira LM, Nisihara R, Utiyama SR, Bem RS, Marcatto C, Bertolazo M \& Carvalho GA. Screening of celiac disease in patients with autoimmune thyroid disease from Southern Brazil. Arquivos Brasileiros de Endocrinologia e Metabologia 201458 625-629. (https:// doi.org/10.1590/0004-2730000003003)

45 Kaukinen K, Collin P, Mykkanen AH, Partanen J, Maki M \& Salmi J. Celiac disease and autoimmune endocrinologic disorders. Digestive Diseases and Sciences 199944 1428-1433. (https://doi. org/10.1023/A:1026612121041)

46 Badenhoop K, Dieterich W, Segni M, Hofmann S, Hufner M, Usadel KH, Hahn EG \& Schuppan D. HLA DQ2 and/or DQ8 is associated with celiac disease-specific autoantibodies to tissue transglutaminase in families with thyroid autoimmunity. American Journal of Gastroenterology 200196 1648-1649. (https://doi. org/10.1111/j.1572-0241.2001.03821.x)

47 Velluzzi F, Caradonna A, Boy MF, Pinna MA, Cabula R, Lai MA, Piras E, Corda G, Mossa P, Atzeni F et al. Thyroid and celiac disease: clinical, serological, and echographic study. American Journal of Gastroenterology 199893 976-979. (https://doi.org/10.1111/j.15720241.1998.291_u.x)
48 Lenhardt A, Plebani A, Marchetti F, Gerarduzzi T, Not T, Meini A, Villanacci V, Martelossi S \& Ventura A. Role of humantissue transglutaminase IgG and anti-gliadin IgG antibodies in the diagnosis of coeliac disease in patients with selective immunoglobulin A deficiency. Digestive and Liver Disease 200436 730-734. (https://doi.org/10.1016/j.dld.2004.06.017)

49 Catassi C, Bearzi I \& Holmes GK. Association of celiac disease and intestinal lymphomas and other cancers. Gastroenterology 2005128 S79-S86. (https://doi.org/10.1053/j.gastro.2005.02.027)

50 Collin P, Kaukinen K, Välimäki M \& Salmi J. Endocrinological disorders and celiac disease. Endocrine Reviews 200224 464-483. (https://doi.org/10.1210/er.2001-0035)

51 Ventura A, Neri E, Ughi C, Leopaldi A, Citta A \& Not T. Glutendependent diabetes-related and thyroid-related autoantibodies in patients with celiac disease. Journal of Pediatrics 2000137 263-265. (https://doi.org/10.1067/mpd.2000.107160)

52 Montalto M, Curigliano V, Santoro L, Vastola M, Cammarota G, Manna R, Gasbarrini A \& Gasbarrini G. Management and treatment of lactose malabsorption. World Journal of Gastroenterology $2006 \mathbf{1 2}$ 187-191. (https://doi.org/10.3748/wjg.v12.i2.187)

53 Lomer MC, Parkes GC \& Sanderson JD. Review article: lactose intolerance in clinical practice - myths and realities. Alimentary Pharmacology and Therapeutics 200827 93-103. (https://doi. org/10.1111/j.1365-2036.2007.03557.x)

54 Ruchała M, Szczepanek-Parulska E \& Zybek A. The influence of lactose intolerance and other gastro-intestinal tract disorders on L-thyroxine absorption. Endokrinologia Polska 201263 318-323.

55 Cellini M, Santaguida MG, Gatto I, Virili C, Del Duca SC, Brusca N, Capriello S, Gargano L \& Centanni M. Systematic appraisal of lactose intolerance as cause of increased need for oral thyroxine. Journal of Clinical Endocrinology and Metabolism 201499 E1454-E14588. (https://doi.org/10.1210/jc.2014-1217)

56 Gadiraj US, Lee CJ \& Cooper DS. Levothyroxine dosing following bariatric surgery. Obesity Surgery 201626 2538-2542. (https://doi. org/10.1007/s11695-016-2314-x)

57 Hommel C \& Delgrande E. Resistance to levothyroxine in a bariatric surgery patient an indication for liquid formulation? Acta Clinica Belgica 201772 72-75. (https://doi.org/10.1080/17843286.2016.1196861)

58 Stone E, Leiter LA, Lambert JR, Silverberg JD, Jeejeebhoy KN \& Burrow GN. L-thyroxine absorption in patients with short bowel. Journal of Clinical Endocrinology and Metabolism 198459 139-141. (https://doi.org/10.1210/jcem-59-1-139)

59 Seppel T, Rose F \& Schlaghecke R. Chronic intestinal giardiasis with isolated levothyroxine malabsorption as reason for severe hypothyroidism-implications for localization of thyroid hormone absorption in the gut. Experimental and Clinical Endocrinology and Diabetes $1996 \mathbf{1 0 4}$ 180-182. (https://doi org/10.1055/s-0029-1211442)

60 Biondi B \& Wartofsky L. Combination treatment with T4 and T3: toward personalized replacement therapy in hypothyroidism? Journal of Clinical Endocrinology and Metabolism 201297 2256-2271. (https:// doi.org/10.1210/jc.2011-3399)

61 Wiersinga WM, Duntas L, Fadeyev V, Nygaard B \& Vanderpump MP. 2012 ETA guidelines: the use of LT4+LT3 in the treatment of hypothyroidism. European Thyroid Journal 20121 55-71. (https://doi. org/10.1159/000339444)

62 Wiersinga WM. Paradigm shifts in thyroid hormone replacement therapies for hypothyroidism. Nature Reviews Endocrinology 201410 164-174. (https://doi.org/10.1038/nrendo.2013.258)

63 Celi FS, Zemskova M, Linderman JD, Babar NI, Skarulis MC, Csako G, Wesley R, Costello R, Penzak SR \& Pucino F. The pharmacodynamic equivalence of levothyroxine and liothyronine: a randomized, double blind, cross-over study in thyroidectomized patients. Clinical Endocrinology 201072 709-715. (https://doi.org/10.1111/j.1365$2265.2009 .03700 . x)$ 
64 Escobar-Morreale HF, del Rey FE, Obregon MJ \& de Escobar GM. Only the combined treatment with thyroxine and triiodothyronine ensures euthyroidism in all tissues of the thyroidectomized rat. Endocrinology 1996137 2490-502. (https://doi.org/10.1210/ endo.137.6.8641203)

65 Smith RN, Taylor SA \& Massey JC. Controlled clinical trial of combined triiodothyronine and thyroxine in the treatment of hypothyroidism. British Medical Journal 19704 145-148. (https://doi org/10.1136/bmj.4.5728.145)

66 Bunevicius R, Kazanavicius G, Zalinkevicius R \& Prange AJ Jr. Effects of thyroxine as compared with thyroxine plus triiodothyronine in patients with hypothyroidism. New England Journal of Medicine 1999 340 424-429. (https://doi.org/10.1056/NEJM199902113400603)

67 Nygaard B, Jensen EW, Kvetny J, Jarlov A \& Faber J.

Effect of combination therapy with thyroxine (T4) and 3,5,3'-triiodothyronine versus T4 monotherapy in patients with hypothyroidism, a double-blind, randomised cross-over study. European Journal of Endocrinolology 2009161 895-902. (https://doi. org/10.1530/EJE-09-0542)

68 Fadeyev VV, Morgunova TB, Melnichenko GA \& Dedov II. Combined therapy with L-thyroxine and L-triiodothyronine compared to L-thyroxine alone in the treatment of primary hypothyroidism. Hormones 20109 245-252. (https://doi.org/10.14310/ horm.2002.1274)

69 Kaminski J, Miasaki FY, Paz-Filho G, Graf H \& Carvalho GA. Treatment of hypothyroidism with levothyroxine plus liothyronine: a randomized, double-blind, crossover study. Archives of Endocrinology and Metabolism $2016 \mathbf{6 0}$ 562-572. (https://doi.org/10.1590/2359. 3997000000192)

70 Walsh JP, Shiels L, Lim EM, Bhagat CI, Ward LC, Stuckey BG, Dhaliwal SS, Chew GT, Bhagat MC \& Cussons AJ. Combined thyroxine/liothyronine treatment does not improve well-being, quality of life, or cognitive function compared to thyroxine alone: a randomized controlled trial in patients with primary hypothyroidism. Journal of Clinical Endocrinology and Metabolism 2003 88 4543-4550. (https://doi.org/10.1210/jc.2003-030249)

71 Appelhof BC, Fliers E, Wekking EM, Schene AH, Huyser J, Tijssen JG, Endert E, van Weert HC \& Wiersinga WM. Combined therapy with levothyroxine and liothyronine in two ratios, compared with levothyroxine monotherapy in primary hypothyroidism: a double-blind, randomized, controlled clinical trial. Journal of Clinical Endocrinology and Metabolism 200590 2666-2674. (https://doi. org/10.1210/jc.2004-2111)

72 Rodriguez T, Lavis VR, Meininger JC, Kapadia AS \& Stafford LF. Substitution of liothyronine at a 1:5 ratio for a portion of levothyroxine: effect on fatigue, symptoms of depression, and working memory versus treatment with levothyroxine alone. Endocrine Practice 200511 223-233. (https://doi.org/10.4158/ EP.11.4.223)

73 Escobar-Morreale HF, Botella-Carretero JI, Gomez-Bueno M, Galan JM, Barrios V \& Sancho J. Thyroid hormone replacement therapy in primary hypothyroidism: a randomized trial comparing L-thyroxine plus liothyronine with L-thyroxine alone. Annals of Internal Medicine 2005142 412-424. (https://doi.org/10.7326/00034819-142-6-200503150-00007)

74 Saravanan P, Simmons DJ, Greenwood R, Peters TJ \& Dayan CM. Partial substitution of thyroxine (T4) with tri-iodothyronine in patients on T4 replacement therapy: results of a large communitybased randomized controlled trial. Journal of Clinical Endocrinology Metabolism 200590 805-812. (https://doi.org/10.1210/jc.2004-1672)

75 Grozinsky-Glasberg S, Fraser A, Nahshoni E, Weizman A \& Leibovici L. Thyroxine-triiodothyronine combination therapy versus thyroxine monotherapy for clinical hypothyroidism: meta-analysis of randomized controlled trials. Journal of Clinical Endocrinology and Metabolism 200691 2592-2599. (https://doi.org/10.1210/jc.20060448)
76 Ma C, Xie J, Huang X, Wang G, Wang Y, Wang X \& Zuo S. Thyroxine alone or thyroxine plus triiodothyronine replacement therapy for hypothyroidism. Nuclear Medicine Communications 200930 586-593. (https://doi.org/10.1097/MNM.0b013e32832c79e0)

77 Medici M, Chaker L \& Peeters RP. A step forward in understanding the relevance of genetic variation in type 2 deiodinase. Journal of Clinical Endocrinology and Metabolism 2017102 1775-1778. (https:// doi.org/10.1210/jc.2017-00585)

78 Guerra A, Sapio MR, Carrano M, Di Stasi V, Volpe A, Murino A, Izzo G \& Vitale M. Prevalence of Dio2(T92A) polymorphism and its association with thyroid autoimmunity. Journal of Endocrinological Investigation 201336 303-306. (https://doi.org/10.3275/8618)

79 de Jong FJ, Peeters RP, den Heijer T, van der Deure WM, Hofman A, Uitterlinden AG, Visser TJ \& Breteler MM. The association of polymorphisms in the type 1 and 2 deiodinase genes with circulating thyroid hormone parameters and atrophy of the medial temporal lobe. Journal of Clinical Endocrinology Metabolism 200792 636-640. (https://doi.org/10.1210/jc.2006-1331)

80 Peeters RP, van Toor H, Klootwijk W, de Rijke YB, Kuiper GG, Uitterlinden AG \& Visser TJ. Polymorphisms in thyroid hormone pathway genes are associated with plasma TSH and iodothyronine levels in healthy subjects. Journal of Clinical Endocrinology Metabolism 200388 2880-2888. (https://doi.org/10.1210/jc.2002-021592)

81 Gumieniak O, Perlstein TS, Williams JS, Hopkins PN, Brown NJ, Raby BA \& Williams GH. Ala92 type 2 deiodinase allele increases risk for the development of hypertension. Hypertension $2007 \mathbf{4 9}$ 461-466. (https://doi.org/10.1161/01.HYP.0000256295.72185.fd)

82 Wouters HJ, van Loon HC, van der Klauw MM, Elderson MF, Slagter SN, Kobold AM, Kema IP, Links TP, van Vliet-Ostaptchouk JV $\&$ Wolffenbuttel BH. No effect of the Thr92Ala polymorphism of deiodinase- 2 on thyroid hormone parameters, health-related quality of life, and cognitive functioning in a large population-based cohort study. Thyroid 201727 147-155. (https://doi.org/10.1089/ thy.2016.0199)

83 Castagna MG, Dentice M, Cantara S, Ambrosio R, Maino F, Porcelli T, Marzocchi C, Garbi C, Pacini F \& Salvatore D. DIO2 Thr92Ala reduces deiodinase-2 activity and serum-t3 levels in thyroid-deficient patients. Journal of Clinical Endocrinology and Metabolism 2017102 1623-1630. (https://doi.org/10.1210/jc.2016-2587)

84 Biondi B \& Cooper DS. The clinical significance of subclinical hypothyroidism. Endocrine Reviews 200829 76-131. (https://doi. org/10.1210/er.2006-0043)

85 Bemben DA, Hamm RM, Morgan L, Winn P, Davis A \& Barton E. Thyroid disease in the elderly. Part 2. Predictability of subclinical hypothyroidism. Journal of Family Practice 199438 583-588.

86 Bell RJ, Rivera-Woll L, Davison SL, Topliss DJ, Donath S \& Davis SR. Well-being, health-related quality of life and cardiovascular disease risk profile in women with subclinical thyroid disease - a community-based study. Clinical Endocrinology 200766 548-556. (https://doi.org/10.1111/j.1365-2265.2007.02771.x)

87 Abreu IM, Lau E, de Sousa Pinto B \& Carvalho D. Subclinical hypothyroidism: to treat or not to treat, that is the question! A systematic review with meta-analysis on lipid profile. Endocrine Connections 20176 188-199. (https://doi.org/10.1530/EC-17-0028)

88 Duntas LH. Thyroid disease and lipids. Thyroid 200212 287-293. (https://doi.org/10.1089/10507250252949405)

89 Cappola AR \& Ladenson PW. Hypothyroidism and atherosclerosis. Journal of Clinical Endocrinology and Metabolism 200388 2438-2444. (https://doi.org/10.1210/jc.2003-030398)

90 Liu D, Jiang F, Shan Z, Wang B, Wang J, Lai Y, Chen Y, Li M, Liu H, $\mathrm{Li} \mathrm{C}$ et al. A cross-sectional survey of relationship between serum TSH level and blood pressure. Journal of Human Hypertension 201024 134-138. (https://doi.org/10.1038/jhh.2009.44)

91 Fox CS, Pencina MJ, D’Agostino RB, Murabito JM, Seely EW, Pearce EN \& Vasan RS. Relations of thyroid function to body weight: cross-sectional and longitudinal observations in a community-based 
sample. Archives of Internal Medicine 2008168 587-592. (https://doi. org/10.1001/archinte.168.6.587)

92 Maratou E, Hadjidakis DJ, Kollias A, Tsegka K, Peppa M, Alevizaki M, Mitrou P, Lambadiari V, Boutati E, Nikzas D et al. Studies of insulin resistance in patients with clinical and subclinical hypothyroidism. European Journal of Endocrinology 2009160 785-790. (https://doi. org/10.1530/EJE-08-0797)

93 Rodondi N, den Elzen WP, Bauer DC, Cappola AR, Razvi S, Walsh JP, Asvold BO, Iervasi G, Imaizumi M, Collet TH et al. Subclinical hypothyroidism and the risk of coronary heart disease and mortality. JAMA 2010304 1365-1374. (https://doi.org/10.1001/ jama.2010.1361)

94 Selmer C, Olesen JB, Hansen ML, von Kappelgaard LM, Madsen JC, Hansen PR, Pedersen OD, Faber J, Torp-Pedersen C \& Gislason GH. Subclinical and overt thyroid dysfunction and risk of all-cause mortality and cardiovascular events: a large population study. Journal of Clinical Endocrinology and Metabolism 201499 2372-2382. (https:// doi.org/10.1210/jc.2013-4184)

95 Sgarbi JA, Teixeira PF, Maciel LM, Mazeto GM, Vaisman M, Montenegro Junior RM, Ward LS \& Brazilian Society of Endocrinology and Metabolism. The Brazilian consensus for the clinical approach and treatment of subclinical hypothyroidism in adults: recommendations of the thyroid Department of the Brazilian Society of Endocrinology and Metabolism. Arquivos Brasileiros de Endocrinologia e Metabologia 201357 166-183. (https://doi. org/10.1590/S0004-27302013000300003)

96 Díez JJ, Iglesias P \& Burman KD. Spontaneous normalization of thyrotropin concentrations in patients with subclinical hypothyroidism. Journal of Clinical Endocrinology and Metabolism 2005 90 4124-4127. (https://doi.org/10.1210/jc.2005-0375)

97 Burns RB, Bates CK, Hartzband P \& Smetana GW. Should we treat for subclinical hypothyroidism? Grand rounds discussion from Beth Israel Deaconess Medical Center. Annals of Internal Medicine 2016164 764-770. (https://doi.org/10.7326/M16-0857)

98 Vanderpump MP, Tunbridge WM, French JM, Appleton D, Bates D, Clark F, Grimley Evans J, Hasan DM, Rodgers H, Tunbridge F et al. The incidence of thyroid disorders in the community: a twenty-year follow-up of the Whickham Survey. Clinical Endocrinology 199543 55-68. (https://doi.org/10.1111/j.1365-2265.1995.tb01894.x)

99 Basaria S \& Cooper DS. Amiodarone and the thyroid. American Journal of Medicine 2005118 706-714. (https://doi.org/10.1016/j. amjmed.2004.11.028)

100 Klein I \& Danzi S. Thyroid disease and the heart. Circulation 2007116 1725-1735. (https://doi.org/10.1161/ CIRCULATIONAHA.106.678326)

101 Danzi S \& Klein I. Recent considerations in the treatment of hypothyroidism. Current Opinion in Investigation Drugs 20089 357-362.

102 Gharib H, Tuttle RM, Baskin HJ, Fish LH, Singer PA \& McDermott MT. Subclinical thyroid dysfunction: a joint statement on management from the American Association of Clinical Endocrinologists, the American Thyroid Association, and the Endocrine Society. Journal of Clinical Endocrinology and Metabolism 200590 581-585. (https://doi.org/10.1210/jc.2004-1231)

103 Biondi B, Palmieri EA, Lombardi G \& Fazio S. Effects of subclinical thyroiddysfunction on the heart. Annals of Internal Medicine 2002137 904-914. (https://doi.org/10.7326/0003-4819-137-11200212030-00011)

104 Klein I \& Ojamaa K. Thyroid hormone and the cardiovascular system. New England Journal of Medicine 2001344 501-509. (https:// doi.org/10.1056/NEJM200102153440707)

105 Biondi B \& Klein I. Hypothyroidism as a risk fator for cardiovascular disease. Endocrine 200424 1-13. (https://doi.org/10.1385/ ENDO:24:1:001)

106 Biondi B, Fazio S, Palmieri EA, Carella C, Panza N, Cittadini A, Bonè $\mathrm{F}$, Lombardi $\mathrm{G} \&$ Saccà L. Left ventricular diastolic dysfunction in patients with subclinical hypothyroidism. Journal of Clinical Endocrinology and Metabolism 199984 2064-2067. (https://doi. org/10.1210/jcem.84.6.5733)

107 Biondi B, Fazio S, Palmieri EA, Tremalaterra R, Angellotti G, Bonè F, Riccio G, Cittadini A, Lombardi G \& Saccà L. Effects of chronic subclinical hyperthyroidism from levothyroxine on cardiac morphology and function. Cardiologia 199944 443-449.

108 Brenta G, Mutti LA, Schnitman M, Fretes O, Perrone A \& Matute ML. Assessment of left ventricular diastolic function by radionuclide ventriculography at rest and exercise in subclinical hypothyroidism, and its response to L-thyroxine therapy. American Journal of Cardiology 200391 1327-1330. (https://doi.org/10.1016/S00029149(03)00322-9)

109 Monzani F, Di Bello V, Caraccio N, Bertini A, Giorgi D, Giusti C \& Ferrannini E. Effect of levothyroxine on cardiac function and structure in subclinical hypothyroidism: a double blind, placebocontrolled study. Journal of Clinical Endocrinology and Metabolism 2001 86 1110-1115. (https://doi.org/10.1210/jcem.86.3.7291)

110 Taylor DJ, Rajagopalan B \& Radda GK. Cellular energetics in hypothyroid muscle. European Journal of Clinical Investigation 199222 358-365. (https://doi.org/10.1111/j.1365-2362.1992.tb01474.x)

111 Caiozzo VJ, Baker MJ \& Baldwin KM. Novel transitions in MHC isoforms: separate and combined effects of thyroid hormone and mechanical unloading. Journal of Applied Physiology (1985) 199885 2237-2248. (https://doi.org/10.1152/jappl.1998.85.6.2237)

112 Kaminsky P, Robin-Lherbier B, Brunotte F, Escanye JM, Walker P, Klein M, Robert J \& Duc M. Energetic metabolism in hypothyroid skeletal muscle, as studied by phosphorus magnetic resonance spectroscopy. Journal of Clinical Endocrinology and Metabolism $1992 \mathbf{7 4}$ 124-129. (https://doi.org/10.1210/jcem.74.1.1727810)

113 Argov Z, Renshaw PF, Boden B, Winokur A \& Bank WJ. Effects of thyroid hormones on skeletal muscle bioenergetics. In vivo phosphorus-31 magnetic resonance spectroscopy study of humans and rats. Journal of Clinical Investigation 198881 1695-1701. (https:// doi.org/10.1172/JCI113508)

114 Stott DJ, Rodondi N, Bauer DC \& TRUST Study Group. Thyroid hormone therapy for older adults with subclinical hypothyroidism. New England Journal of Medicine 2017377 e20. (https://doi. org/10.1056/NEJMc1709989)

115 Peters RP. Subclinical hypothyroidism. New England Journal of Medicine 2017376 2556-2565. (https://doi.org/10.1056/ NEJMcp1611144)

116 Peleg RK, Efrati S, Benbassat C, Fygenzo M \& Golik A. The effect of levothyroxine on arterial stiffness and lipid profile in patients with subclinical hypothyroidism. Thyroid 200818 825-830. (https://doi. org/10.1089/thy.2007.0359)

117 Yazici M, Gorgulu S, Sertbas Y, Erbilen E, Albayrak S, Yildiz O \& Uyan C. Effects of thyroxin therapy on cardiac function in patients with subclinical hypothyroidism: index of myocardial performance in the evaluation of left ventricular function. International Journal of Cardiology 200495 135-143. (https://doi.org/10.1016/j. ijcard.2003.05.015)

118 Nyström E, Caidahl K, Fager G, Wikkelsö C, Lundberg PA \& Lindstedt G. A double-blind cross-over 12-month study of L-thyroxine treatment of women with 'subclinical' hypothyroidism. Clinical Endocrinology 198829 63-75.

119 Kahaly GJ. Thyroid hormone action in the heart. Endocrine Reviews 200526 704-728. (https://doi.org/10.1210/er.2003-0033)

120 Lekakis J, Papamichael C, Alevizaki M, Piperingos G, Marafelia P, Mantzos J, Stamatelopoulos S \& Koutras DA. Flow-mediated, endothelium-dependent vasodilation is impaired in subjects with hypothyroidism, borderline hypothyroidism, and high-normal serum thyrotropin (TSH) values. Thyroid 19977 411-414. (https:// doi.org/10.1089/thy.1997.7.411)

121 Taddei S, Caraccio N, Virdis A, Dardano A, Versari D, Ghiadoni L, Salvetti A, Ferrannini E \& Monzani F. Impaired endothelium- 
dependent vasodilatation in subclinical hypothyroidism: beneficial effect of levothyroxine therapy. Journal of Clinical Endocrinology and Metabolism 200388 3731-3737. (https://doi.org/10.1210/jc.2003030039)

122 Ripoli A, Pingitore A, Favilli B, Bottoni A, Turchi S, Osman NF, De Marchi D, Lombardi M, L'Abbate A \& Iervasi G. Does subclinical hypothyroidism affect cardiac pump performance? Evidence from a magnetic resonance imaging study. Journal of the American College of Cardiology 200545 439-445. Erratum in: Journal of the American College of Cardiology 200545 968. (https://doi.org/10.1016/j. jacc.2004.10.044)

123 Faber J, Petersen L, Wiinberg N, Schifter S \& Mehlsen J. Hemodynamic changes after levothyroxine treatment in subclinical hypothyroidism. Thyroid 200212 319-324. (https://doi. org/10.1089/10507250252949450)

124 Owen PJ, Rajiv C, Vinereanu D, Mathew T, Fraser AG \& Lazarus JH. Subclinical hypothyroidism, arterial stiffness, and myocardial reserve. Journal of Clinical Endocrinology and Metabolism 200691 2126-2132. (https://doi.org/10.1210/jc.2005-2108)

125 Razvi S, Ingoe L, Keeka G, Oates C, McMillan C \& Weaver JU. The beneficial effect of L-thyroxine on cardiovascular risk factors, endothelial function, and quality of life in subclinical hypothyroidism: randomized, crossover trial. Journal of Clinical Endocrinology and Metabolism 200792 1715-1723. (https://doi. org/10.1210/jc.2006-1869)

126 Traub-Weidinger T, Graf S, Beheshti M, Ofluoglu S, Zettinig G, Khorsand A, Nekolla SG, Kletter K, Dudczak R \& Pirich C. Coronary vasoreactivity in subjects with thyroid autoimmunity and subclinical hypothyroidism before and after supplementation with thyroxine. Thyroid 201222 245-251. (https://doi.org/10.1089/thy.2011.0183)

127 Pearce SH, Brabant G, Duntas LH, Monzani F, Peeters RP, Razvi S \& Wemeau JL. 2013 ETA guideline: management of subclinical hypothyroidism. European Thyroid Journal 20132 215-28. (https:// doi.org/10.1159/000356507)

128 Beck-Peccoz P, Rodari G, Giavoli C \& Lania A. Central hypothyroidism - a neglected thyroid disorder. Nature Reviews Endocrinology 201713 588-598. (https://doi.org/10.1038/ nrendo.2017.47)

129 Grunenwald S \& Caron P. Central hypothyroidism in adults: better understanding for better care. Pituitary 201518 169-175. (https:// doi.org/10.1007/s11102-014-0559-8)

130 Yamada M \& Mori M. Mechanisms related to the pathophysiology and management of central hypothyroidism. Nature Clinical Practice Endocrinology and Metabolism 20084 683-694. (https://doi. org/10.1038/ncpendmet0995)

131 Alexopoulou O, Beguin C, De Nayer P \& Maiter D. Clinical and hormonal characteristics of central hypothyroidism at diagnosis and during follow-up in adult patients. European Journal of Endocrinology 2004150 1-8. (https://doi.org/10.1530/eje.0.1500001)

132 Ferretti E, Persani L, Jaffrain-Rea ML, Giambona S, Tamburrano G $\&$ Beck-Peccoz P. Evaluation of the adequacy of levothyroxine replacement therapy in patients with central hypothyroidism. Journal of Clinical Endocrinology and Metabolism 199984 924-929.

133 Brenta G, Vaisman M, Sgarbi JA, Bergoglio LM, Andrada NC, Bravo PP, Orlandi AM, Graf H \& Task Force on Hypothyroidism of the Latin American Thyroid Society (LATS). Clinical practice guidelines for the management of hypothyroidism. Arquivos Brasileiros de Endocrinologia e Metabologia 201357 265-291. (https:// doi.org/10.1590/S0004-27302013000400003)

134 Fish LH, Schwartz HL, Cavanaugh J, Steffes MW, Bantle JP \& Oppenheimer JH. Replacement dose, metabolism, and bioavailability of levothyroxine in the treatment of hypothyroidism. Role of triiodothyronine in pituitary feedback in humans. New England Journal of Medicine 1987316 764-770. (https://doi.org/10.1056/ NEJM198703263161302)

135 Slawik M, Klawitter B, Meiser E, Schories M, Zwermann O, Borm K, Peper M, Lubrich B, Hug MJ, Nauck M et al. Thyroid hormone replacement for central hypothyroidism: a randomized controlled trial comparing two doses of thyroxine (T4) with a combination of T4 and triiodothyronine. Journal of Clinical Endocrinology and Metabolism 200792 4115-4122. (https://doi.org/10.1210/jc.20070297)

136 Koulouri O, Auldin MA, Agarwal R, Kieffer V, Robertson C, Falconer Smith J, Levy MJ \& Howlett TA. Diagnosis and treatment of hypothyroidism in TSH deficiency compared to primary thyroid disease: pituitary patients are at risk of under-replacement with levothyroxine. Clinical Endocrinology 201174 744-749. (https://doi. org/10.1111/j.1365-2265.2011.03984.x)

137 Shimon I, Cohen O, Lubetsky A \& Olchovsky D. Thyrotropin suppression by thyroid hormone replacement is correlated with thyroxine level normalization in central hypothyroidism. Thyroid 200212 823-827. (https://doi. org/10.1089/105072502760339406)

138 Giavoli C, Porretti S, Ferrante E, Cappiello V, Ronchi CL, Travaglini P, Epaminonda P, Arosio M \& Beck-Peccoz P. Recombinant hGH replacement therapy and the hypothalamus-pituitary-thyroid axis in children with GH deficiency: when should we be concerned about the occurrence of central hypothyroidism? Clinical Endocrinology 200359 806-810. (https://doi.org/10.1046/j.13652265.2003.01892.x)

139 Jørgensen JO, Møller J, Laursen T, Orskov H, Christiansen JS \& Weeke J. Growth hormone administration stimulates energy expenditure and extrathyroidal conversion of thyroxine to triiodothyronine in a dose-dependent manner and suppresses circadian thyrotrophin levels: studies in GH-deficient adults. Clinical Endocrinology 199441 609-614.

140 Martins MR, Doin FC, Komatsu WR, Barros-Neto TL, Moises VA \& Abucham J. Growth hormone replacement improves thyroxine biological effects: implications for management of central hypothyroidism. Journal of Clinical Endocrinology and Metabolism 2007 92 4144-4153. (https://doi.org/10.1210/jc.2007-0941)

141 Illouz F, Braun D, Briet C, Schweizer U \& Rodien P. Endocrine side-effects of anti-cancer drugs: thyroid effects of tyrosine kinase inhibitors. European Journal of Endocrinology 2014171 R91-R99. (https://doi.org/10.1530/EJE-14-0198)

142 Hartmann K. Thyroid disorders in the oncology patient. Journal of the Advanced Practitioner in the Oncology Patient 20156 99-106.

143 Desai J, Yassa L, Marqusee E, George S, Frates MC, Chen MH, Morgan JA, Dychter SS, Larsen PR, Demetri GD et al. Hypothyroidism after sunitinib treatment for patients with gastrointestinal stromal tumors. Annals of Internal Medicine 2006145 660-664. (https://doi. org/10.7326/0003-4819-145-9-200611070-00008)

Received 11 November 2017

Revised version received 1 February 2018

Accepted 27 February 2018 